\title{
Voluntary exercise under a food restriction condition decreases blood branched-chain amino acid levels, in addition to improvement of glucose and lipid metabolism, in $d b$ mice, animal model of type 2 diabetes
}

\author{
Ancah Caesarina Novi Marchianti • \\ Emi Arimura • Miharu Ushikai • \\ Masahisa Horiuchi
}

Received: 14 May 2014/ Accepted: 13 July 2014/Published online: 2 August 2014

(C) The Japanese Society for Hygiene 2014

\begin{abstract}
Objectives Exercise is effective for preventing the onset and development of type 2 diabetes mellitus (T2DM) in human cases; however, the effect of exercise on the pathophysiology using animal models of T2DM has not been fully evaluated.

Methods We applied voluntary exercise under pair-fed (P) conditions in $d b$ mice, an animal model of T2DM. Exercising (Ex) and sedentary (Se) mice were placed in a cage, equipped with a free or locked running wheel, for 4 weeks, respectively. The amount of food consumed by ad libitum-fed wild-type mice under the Se condition (adWT) was supplied to all mice, except ad libitum $d b$ mice $($ ad- $-d b)$. Blood parameters and expression of the genes involved in nutrient metabolism were analyzed.

Results PEx- $d b$ (pair-fed and exercising) mice showed significantly lower $\mathrm{HbAlc}$, body weight and liver weight
\end{abstract}

Electronic supplementary material The online version of this article (doi:10.1007/s12199-014-0400-z) contains supplementary material, which is available to authorized users.

A. C. N. Marchianti - E. Arimura · M. Ushikai ·

M. Horiuchi $(\square)$

Department of Hygiene and Health Promotion Medicine,

Kagoshima University Graduate School of Medical and Dental

Sciences, 8-35-1 Sakuragaoka, Kagoshima 890-8544, Japan

e-mail: masakun@m.kufm.kagoshima-u.ac.jp

A. C. N. Marchianti

Faculty of Medicine, Jember University, Jember, Indonesia

E. Arimura

Major in Food and Nutrition, Department of Life and Environmental Science, Kagoshima Prefectural College, Kagoshima, Japan than PSe- $d b$ and ad- $d b$ mice. Decreased hepatic triglycerides in PEx- $d b$ mice corresponded to a lower expression of lipogenic enzyme genes in the liver. Moreover, PEx- $d b$ mice showed significantly lower plasma branched-chain amino acids (BCAA), arginine, proline, and tyrosine, in addition to increased skeletal muscle (SM) weight, than PSe- $d b$ and ad- $d b$ mice, in spite of little influence on the expression of the BCAA transaminase gene, in SM and WAT.

Conclusion We found that exercise under a food restriction condition decreases several amino acids, including BCAA, and may improve insulin sensitivity more than mere food restriction. We propose that the decreased concentration of blood amino acids may be a valuable marker evaluating the effects of exercise on diabetic conditions.

Keywords Animal model - Exercise - Gene expression · Nutrition · Type 2 diabetes mellitus

$\begin{array}{ll}\text { Abbreviations } \\ \text { AA } & \text { Amino acid } \\ \text { ad } & \text { Ad libitum } \\ \text { BCAA } & \text { Branched-chain amino acids } \\ \text { PEx } & \text { Pair-fed and exercising } \\ \text { FFA } & \text { Free fatty acids } \\ \text { HDL } & \text { High-density lipoprotein } \\ \text { PSe } & \text { Pair-fed and sedentary } \\ \text { SLC } & \text { Solute-linked carrier } \\ \text { SM } & \text { Skeletal muscle } \\ \text { T2DM } & \text { Type 2 diabetes mellitus } \\ \text { TG } & \text { Triglyceride } \\ \text { VE } & \text { Voluntary exercise } \\ \text { WAT } & \text { White adipose tissue } \\ \text { WT } & \text { Wild type }\end{array}$




\section{Introduction}

The incidence of type 2 diabetes mellitus (T2DM) has recently grown worldwide [1,2]. Although T2DM has genetic predispositions, it is unlikely that the gene pool has changed appreciably over this short period of time [3,4]. Thus, the growing incidence of T2DM may be related to lifestyle factors rather than genetic factors [1-4]. Exercise, one of these lifestyle factors, has markedly reduced in the past several decades, especially in developed countries [1, 5, 6]. As appropriate exercise, the Centers for Disease Control and Prevention and the American College of Sports Medicine have jointly published recommendations that adults should engage in at least $30 \mathrm{~min}$ of moderate physical activity (e.g., brisk walking) on most, and preferably all, days of the week [6]; therefore, the impact of exercise (long-term, moderate physical activity, aerobic, and voluntary), representing habitual exercise, on increased glucose uptake and fat oxidation has been elucidated [7, 8]. However, the effect of exercise on organs such as the liver and brain, which are difficult to obtain, is difficult to examine in humans. Therefore, we are obliged to perform experiments using experimental animals at present.

Using mouse models of T2DM, the effect of exercise on pathological conditions, including glucose and lipid metabolism has been examined [9-11]. In previous studies, voluntary exercise (VE) and forced exercise, such as treadmill and swimming, have been applied [9-11]. VE may be more physiological; however, mice with T2DM have been reported to perform a small amount of exercise voluntarily $[12,13]$, which is similar to people with T2DM [14]. In these reports, even VE failed to reverse defects in glucose and insulin levels in $d b$ mice with leptin receptor deficiency, an animal model of T2DM [12, 13]. On the other hand, a food restriction, pair-fed procedure suppressed weight gain, but did not restore fat content and glucose levels $[15,16]$. Recently, Stranahan et al. reported that $60 \%$ food restriction increased VE in $d b$ mice, showing the effect of a combination of food and exercise interventions [17]. Stranahan et al. [17] reported the effect of exercise on metabolite levels of glucose and lipid metabolism, and brain function; however, the effect of exercise on gene expressions related to glucose and lipid metabolism has not been examined. Additionally, the effect of exercise on amino acid (AA) metabolism has not been examined. In animals and humans with type $2 \mathrm{DM}$, a higher concentration of blood branched-chain amino acids has been noted [18-20]; therefore, we examined the effect of exercise on AA metabolism, in addition to glucose and lipid metabolism.

The purpose of the present study was to establish an animal model of T2DM to evaluate the effect of exercise in an animal model of T2DM under a food restriction condition by means of a pair-fed procedure. Using this model, we examined the effects of exercise on AA metabolism, in addition to glucose and lipid metabolism in $d b$ mice. Additionally, we tried to examine the effects of exercise on mRNA levels of the genes related to nutrient metabolism in the liver, skeletal muscle (SM), and white adipose tissue (WAT), representing insulin-sensitive organs.

\section{Materials and methods}

Animals and pair-fed conditions

Male mice with diabetes [C57BLKS(BKS).Cg- + Lepr $^{d b}$ / $\left.+\operatorname{Lepr}^{d b} / \mathrm{J} ; d b\right]$, having a homozygous mutation of the leptin receptor, and control (BKS.Cg-Dock7 ${ }^{\mathrm{m}}+$ / Dock $7^{\mathrm{m}}+/ \mathrm{J}$; WT, mice without diabetes) mice at 4 weeks of age were purchased from Charles River Japan (Kanagawa, Japan) [21]. After 3 days' acclimation, as exercising (Ex) or sedentary (Se) conditions, mice were individually housed in a cage with a running wheel or a locked wheel, respectively. They were kept at a constant room temperature of $22 \pm 2{ }^{\circ} \mathrm{C}$, with $12 \mathrm{~h}$ of illumination (07:00-19:00). WT mice and $d b$ mice were subjected to the following 5 conditions for 25 days: (1) ad-WT mice: ad libitum and sedentary, (2) PEx-WT mice: pair-fed and exercise, (3) ad- $d b$ mice: ad libitum and sedentary, (4) PSe- $d b$ mice: pair-fed and sedentary, and (5) PEx- $d b$ mice: pair-fed and exercise. Food (14.4 kJ/g, CE-2; CLEA, Tokyo, Japan), which was equal to the food consumed by ad-WT mice under the ad libitum-fed condition in 1 day, was supplied to the mouse group under pair-fed conditions every day at 17:00 (food consumption during the experimental period: ad- $d b$ mice: $181.2 \pm 7.3 \mathrm{~g}$, pair-fed group mice: $103.5 \mathrm{~g}$ ). On the last day for ad-WT mice, we measured the amount of food consumed by the mice during 17:00-19:00, resulting in $0.8 \mathrm{~g}$ food per mouse. The next day, we supplied $0.8 \mathrm{~g}$ food to the remaining groups of mice at 17:00, and then killed the mice after $2 \mathrm{~h}$, meaning that the mice were treated as being under feeding conditions. Finally, for analysis, blood was taken from the heart, and then the organs were removed. Blood parameters and mRNA levels of the gene related to AA, glucose, and lipid metabolism in the liver, SM (soleus) and WAT (fat surrounding epididymis) were examined.

The present study was approved by the Ethics Committee for Animal Experimentation at Kagoshima University, which is standardized to the Japanese national guideline for animal experiments, and the principles of laboratory animal care were followed. 
Biochemical parameters

Blood $(0.5 \mathrm{ml})$ was drawn from the heart with a syringe containing $0.2 \mathrm{~mol} / \mathrm{l}$ EDTA $(10 \mu \mathrm{l})$, and organs including the heart, liver, SM, and WAT were isolated [22]. The organs were rinsed in isotonic saline, weighed, and quickly frozen in liquid nitrogen. The blood was centrifuged at 3,000 rpm for 5 min for separation of plasma. The plasma and frozen organs were stored at $-80^{\circ} \mathrm{C}$ until analysis. Leptin, insulin, adiponectin, and corticosterone were measured by the respective ELISA kits (R\&D Systems, Minneapolis, MN; Morinaga Institute of Biological Science Inc., Kanagawa, Japan; Otsuka Pharmaceutical Co., Tokyo, Japan; Enzo Life Sciences Inc., Plymouth Meeting, PA, respectively). HbA1c was measured by an immunoassay (DCA 2000 system; Bayer Diagnostics, Elkhart, IN). Plasma amino acid concentrations were determined with a JLC-500 model amino acid analyzer (JEOL, Tokyo, Japan) after deproteinization with $5 \%(\mathrm{w} / \mathrm{v})$ sulfosalicylic acid [23]. Glucose, free fatty acids (FFA), triglyceride (TG), total cholesterol, and highdensity lipoprotein (HDL) cholesterol were measured using the respective kits (Wako, Osaka, Japan). The frozen liver was weighed and added to lipid extraction solution composed of methanol-chloroform, and then homogenized. The organic phase was transferred to glass tubes, evaporated with nitrogen gas, reconstituted in an isopropanol-Triton X-100 mixture $(10 \% \mathrm{v} / \mathrm{v})$, and then vortexed [24]. Lipid content was measured with kits (TG, TG-E test Wako; T-Cho, ChoCII test Wako).

\section{Gene expressions}

The liver, SM, and WAT were used for isolation of total RNA [25]. Isolated RNA was treated with DNase treatment to remove genomic contamination. First-strand cDNA synthesis was performed using $5 \mu \mathrm{g}$ total RNA with oligo$(\mathrm{dT})_{20}$ primer following the manufacturer's instructions (Invitrogen, Carlsbad, CA). Real-time quantitative PCR was performed using SYBR-green on a TAKARA detection system (TAKARA, Shiga, Japan) under the conditions recommended by the manufacturer. The primary sequences of the genes are shown in supplementary Table $1[26,27]$. The relative level of mRNA was calculated using cycle time $(\mathrm{Ct})$ values, which were normalized against the value of $\beta$ tubulin. Relative quantification (fold change) between different samples was then determined according to the $2^{-\triangle \triangle \mathrm{Ct}}$ method. Due to the high variation in gene expression data of ad-WT, the level of the genes in ad- $d b$ mice was set at 1.0.

\section{Statistical analyses}

Values are presented as the mean \pm standard error (SE). The unpaired Student's $t$ test was applied as appropriate to identify significant differences between groups, using Ekuseru-Tokei 2008 software (SSRI Co., Ltd., Tokyo, Japan), with $P<0.05$ as the criterion.

\section{Results}

Running distance and food intake

We preliminarily measured the amount of exercise by $d b$ mice at 4 weeks of age under ad libitum conditions. $d b$ Mice performed significantly less exercise than WT mice, represented as the wheel-running distance $(0.7 \pm 0.1$ vs. $4.5 \pm 0.5 \mathrm{~km} /$ day, $N=4 ; P<0.05)$. Regarding food intake, ad libitum $d b$ mice consumed significantly more food than WT mice for the first week after starting exercise $(5.8 \pm 0.1$ vs. $4.0 \pm 0.1 \mathrm{~g} / \mathrm{day}, N=4 ; P<0.05)$. Under pair-fed conditions where the amount of food consumed by ad-WT mice was supplied to $d b$ mice, the $d b$ mice under the food restriction (Fig. 1A) performed more exercise than ad- $d b$ mice at 4 weeks $(1.7 \pm 1.3$ vs. $0.7 \pm 0.1 \mathrm{~km} /$ day, $N=6$ and $N=4$, respectively). During the experimental period for 4 weeks, WT mice performed an increased amount of exercise under the conditions, whereas $d b$ mice showed largely constant values even under food restriction conditions (Fig. 1A). $d b$ Mice performed significantly less exercise than WT mice, except 1 week after starting the exercise.

Body weight and organ weight

As shown in Fig. 1B, all groups of $d b$ mice weighed significantly more than WT mice at 4 weeks of age before exercise. In 1 week, $d b$ mice under pair-fed condition with and without exercise weighed significantly less than ad- $d b$ mice. Two weeks after exercise under pair-feeding conditions, PEx mice with both genetic traits weighed significantly less than the mice under the sedentary condition (adWT and PSe- $d b$ mice), respectively. Body weight gain is shown in Fig. 1C. PEx mice with both genetic traits had significantly lower body weight gain than mice under the sedentary condition (ad-WT and PSe- $d b$ mice), respectively. This may be due to increased energy expenditure by exercise. As shown in Table 1, PEx- $d b$ had significantly higher weight of SM, and there was a tendency toward increased weight of SM in PEx-WT $(P=0.13)$ as compared to Se mice (ad-WT and PSe- $d b$ mice) with the respective genetic trait. ad- $d b$ Mice had significantly higher liver and WAT weight than the other 4 groups of mice (Table 1). PSe- and PEx- $d b$ mice showed significantly lower heart weight than ad- $d b$ mice. PEx- $d b$ mice had significantly lower liver and WAT weight than PSe- $d b$ mice, as well as WT mice (Table 1). Based on the ratio of 

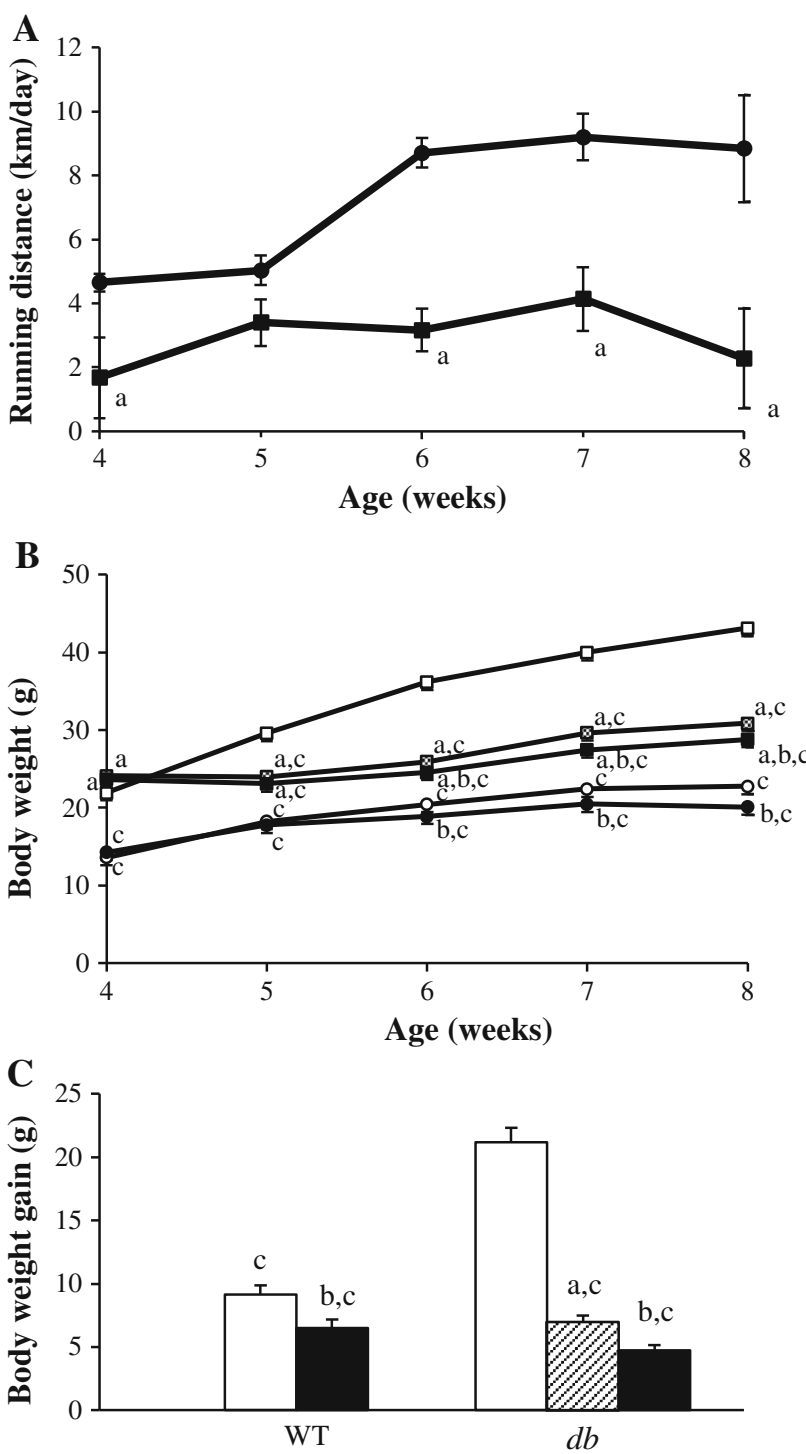

Fig. 1 Body weight and voluntary exercise during the experimental period. Amount of voluntary exercise (A), body weight $(\mathbf{B})$, and body weight gain before exercise and at 8 weeks (C) are shown. Circles and squares represent WT and $d b$ mice, respectively. Closed symbols represent exercising mice under the pair-fed condition (food amount consumed by ad libitum-fed WT mice was supplied). Open symbols represent ad libitum-fed mice under the sedentary condition. Hatched symbols represent pair-fed $d b$ mice under the sedentary condition (PSe- $d b$ mice). The values are the mean \pm SE (A), the means - SE (B), or the means + SE (c), as appropriate. Values were analyzed by Student's $t$ test. In (A) and (B), ${ }^{\mathrm{a}} P<0.05$ vs. WT mice in each physical condition at the same time point. ${ }^{\mathrm{b}} P<0.05 \mathrm{vs}$. ad-WT mice or PSe- $d b$ mice at the same time point. ${ }^{\mathrm{c}} P<0.05 \mathrm{vs}$. ad- $d b$ mice at the same time point. In $(\mathbf{C}),{ }^{\mathrm{a}} P<0.05$ vs. WT mice in each physical condition. ${ }^{\mathrm{b}} P<0.05$ vs. ad-WT mice or PSe- $d b$ mice. ${ }^{\mathrm{c}} P<0.05$ vs. ad- $d b$ mice

organ weights divided by the body weight, PEx-WT mice showed a significantly lower ratio of WAT compared to adWT mice, and a significantly higher ratio of SM for both genetic traits of mice compared with mice under sedentary conditions.
Biochemical parameters including hormones of glucose and lipid metabolism

As shown in Table 1 , PEx- $d b$ mice showed significantly lower plasma insulin, leptin, and corticosterone, and higher plasma adiponectin than PSe- $d b$ mice. For plasma glucose, PEx- $d b$ mice showed a similar level to PSe- $d b$ mice, but a significantly lower level than ad- $d b$ mice. Regarding the relationship between plasma glucose and insulin, PEx- $d b$ mice showed a similar result to ad- and PEx-WT mice, rather than ad- and PSe- $d b$ mice, as shown in Fig. 2. This finding suggests that exercise improved insulin sensitivity in $d b$ mice, corresponding to the results of $\mathrm{HbAlc}$ (Table 1). Although PSe- $d b$ mice showed significantly higher plasma corticosterone than ad- $d b$ mice, the level in PEx- $d b$ mice was significantly lower than in PSe- $d b$ mice. In the liver, PEx- $d b$ mice showed significantly lower triglyceride content as $\mathrm{mg} / \mathrm{liver}$ than PSe- $d b$ mice. On the other hand, PEx- $d b$ showed a similar cholesterol level to PSe- $d b$ mice $(P=0.43)$.

Amino acids

As shown in Table 2, PEx- $d b$ mice showed significantly lower arginine, isoleucine, leucine, ornithine, proline, tyrosine, and valine than PSe- $d b$ mice. As compared to ad$d b$ mice, PSe- $d b$ and PEx- $d b$ mice showed significantly lower cystine, histidine, isoleucine, leucine, phenylalanine, and tryptophan. Namely, arginine, ornithine, proline, tyrosine and valine were significantly lower in PEx- $d b$ mice, but not in PSe- $d b$ mice than in ad- $d b$ mice. For BCAA (isoleucine, leucine and valine), $\mathrm{PEx}-d b$ mice showed a significantly lower level than PSe- $d b$ and ad- $d b$ mice.

Gene expressions related to glucose, lipid, and AA metabolism

To reveal the mechanism involved in the improvement of pathological parameters by VE, we examined the mRNA levels of the genes related to glucose, lipid, and AA metabolism. Ex- $d b$ mice showed significantly lower expression of glucose transporter (Glut) 2 and fatty acid synthase $(F A S)$ in the liver than ad- $d b$ mice (Fig. 3a). There was a tendency toward lower acetyl-CoA carboxylase $(A C C) 1$ expression levels in the liver of PEx- $d b$ mice as compared to ad- $d b$ mice $(P=0.12)$. For glucose 6 phosphatase (G6Pase) expression, PEx- $d b$ mice showed similar levels to ad- $d b$ mice, but there was a significantly lower level in PSe- $d b$ mice as compared to ad- $d b$ mice. In phosphoenol pyruvate carboxykinase (PEPCK) expression, PEx $-d b$ mice showed similar levels to ad- $d b$ and PSe- $d b$ mice. In SM and WAT, PEx- $d b$ mice showed significantly 
Table 1 Effect of voluntary exercise on organ weight and biochemical parameters

\begin{tabular}{|c|c|c|c|c|c|c|}
\hline \multirow[b]{2}{*}{$\begin{array}{l}\text { Fed condition } \\
\text { Physical condition }\end{array}$} & & \multicolumn{5}{|l|}{ Group } \\
\hline & & $\begin{array}{l}\text { ad-WT } \\
\text { ad libitum } \\
\text { sedentary } \\
(N=4)\end{array}$ & $\begin{array}{l}\text { PEx-WT } \\
\text { Pair-fed } \\
\text { exercising } \\
(N=6)\end{array}$ & $\begin{array}{l}a d-d b \\
\text { ad libitum } \\
\text { sedentary } \\
(N=4)\end{array}$ & $\begin{array}{l}\text { PSe- } d b \\
\text { Pair-fed } \\
\text { sedentary } \\
(N=6)\end{array}$ & $\begin{array}{l}\text { PEx-db } \\
\text { Pair-fed } \\
\text { exercising } \\
(N=6)\end{array}$ \\
\hline \multicolumn{7}{|l|}{ Organs } \\
\hline \multirow[t]{2}{*}{ Liver } & $\mathrm{g}$ & $1.06 \pm 0.02^{\mathrm{c}}$ & $0.98 \pm 0.02^{\mathrm{b}, \mathrm{c}}$ & $2.92 \pm 0.14$ & $1.42 \pm 0.06^{\mathrm{a}, \mathrm{c}}$ & $1.26 \pm 0.03^{\mathrm{a}, \mathrm{b}, \mathrm{c}}$ \\
\hline & $\mathrm{mg} / \mathrm{g} \mathrm{BW}$ & $46.7 \pm 1.0^{\mathrm{c}}$ & $48.1 \pm 0.1^{\mathrm{c}}$ & $67.7 \pm 2.6$ & $46.6 \pm 2.2^{\mathrm{c}}$ & $43.5 \pm 0.9^{\mathrm{a}, \mathrm{c}}$ \\
\hline \multirow[t]{2}{*}{ WAT } & $\mathrm{g}$ & $0.29 \pm 0.01^{\mathrm{c}}$ & $0.19 \pm 0.01^{\mathrm{b}, \mathrm{c}}$ & $2.03 \pm 0.08$ & $1.33 \pm 0.06^{\mathrm{a}, \mathrm{c}}$ & $1.12 \pm 0.06^{\mathrm{a}, \mathrm{b}, \mathrm{c}}$ \\
\hline & $\mathrm{mg} / \mathrm{g} \mathrm{BW}$ & $12.9 \pm 0.4^{\mathrm{c}}$ & $9.0 \pm 0.7^{\mathrm{b}, \mathrm{c}}$ & $47.0 \pm 1.5$ & $43.6 \pm 1.3^{\mathrm{a}}$ & $39.9 \pm 1.2^{\mathrm{a}, \mathrm{c}}$ \\
\hline \multirow[t]{2}{*}{ Heart } & $\mathrm{mg}$ & $111 \pm 2$ & $109 \pm 8$ & $113 \pm 1$ & $95 \pm 2^{\mathrm{a}, \mathrm{c}}$ & $93 \pm 4^{\mathrm{c}}$ \\
\hline & $\mathrm{mg} / \mathrm{g} \mathrm{BW}$ & $4.9 \pm 0.1^{\mathrm{c}}$ & $5.4 \pm 0.4^{\mathrm{c}}$ & $2.6 \pm 0.1$ & $3.1 \pm 0.1^{\mathrm{a}, \mathrm{c}}$ & $3.2 \pm 0.1^{\mathrm{a}, \mathrm{c}}$ \\
\hline \multirow[t]{2}{*}{ SM (soleus) } & $\mathrm{mg}$ & $7.1 \pm 1.1$ & $9.1 \pm 0.6$ & $8.6 \pm 0.5$ & $8.4 \pm 0.5$ & $10.1 \pm 0.6^{\mathrm{b}}$ \\
\hline & $\mathrm{mg} / \mathrm{g} \mathrm{BW}$ & $0.3 \pm 0.1$ & $0.5 \pm 0.0^{\mathrm{b}, \mathrm{c}}$ & $0.2 \pm 0.0$ & $0.3 \pm 0.0^{\mathrm{c}}$ & $0.4 \pm 0.0^{\mathrm{a}, \mathrm{b}, \mathrm{c}}$ \\
\hline \multicolumn{7}{|l|}{ Plasma } \\
\hline Glucose & $\mathrm{mmol} / \mathrm{L}$ & $10.4 \pm 0.5^{\mathrm{c}}$ & $8.8 \pm 0.4^{\mathrm{b}, \mathrm{c}}$ & $34.0 \pm 5.2$ & $9.8 \pm 1.0^{\mathrm{c}}$ & $9.0 \pm 0.8^{\mathrm{c}}$ \\
\hline FFA & $\mathrm{mmol} / \mathrm{L}$ & $0.4 \pm 0.1$ & $0.2 \pm 0.0^{\mathrm{c}}$ & $0.5 \pm 0.1$ & $0.4 \pm 0.0$ & $0.4 \pm 0.1^{\mathrm{a}}$ \\
\hline TG & $\mathrm{mmol} / \mathrm{L}$ & $0.6 \pm 0.1^{\mathrm{c}}$ & $0.6 \pm 0.1^{\mathrm{c}}$ & $1.0 \pm 0.1$ & $0.7 \pm 0.1$ & $0.6 \pm 0.0^{\mathrm{c}}$ \\
\hline Total cholesterol & $\mathrm{mmol} / \mathrm{L}$ & $2.4 \pm 0.1^{\mathrm{c}}$ & $1.9 \pm 0.2^{\mathrm{c}}$ & $4.0 \pm 0.2$ & $2.7 \pm 0.1^{\mathrm{a}, \mathrm{c}}$ & $2.3 \pm 0.2^{\mathrm{c}}$ \\
\hline HDL-cholesterol & $\mathrm{mmol} / \mathrm{L}$ & $1.4 \pm 0.1^{\mathrm{c}}$ & $1.1 \pm 0.0^{\mathrm{b}, \mathrm{c}}$ & $2.3 \pm 0.1$ & $1.4 \pm 0.0^{\mathrm{c}}$ & $1.3 \pm 0.1^{\mathrm{c}}$ \\
\hline Insulin & $\mathrm{pmol} / \mathrm{L}$ & $167.0 \pm 58.9^{\mathrm{c}}$ & $129.1 \pm 16.0^{\mathrm{c}}$ & $1485.8 \pm 365.0$ & $1698.1 \pm 282.9^{\mathrm{a}}$ & $438.0 \pm 62.7^{\mathrm{a}, \mathrm{b}, \mathrm{c}}$ \\
\hline Leptin & $\mu \mathrm{g} / \mathrm{L}$ & $6.8 \pm 0.5^{\mathrm{c}}$ & $7.4 \pm 0.7^{\mathrm{c}}$ & $95.8 \pm 6.2$ & $90.6 \pm 2.2^{\mathrm{a}}$ & $75.5 \pm 4.5^{\mathrm{a}, \mathrm{b}, \mathrm{c}}$ \\
\hline Adiponectin & $\mu \mathrm{g} / \mathrm{mL}$ & $12.2 \pm 0.6$ & $15.2 \pm 0.9^{\mathrm{b}}$ & $13.2 \pm 0.4$ & $13.3 \pm 1.0$ & $16.3 \pm 0.3^{\mathrm{b}, \mathrm{c}}$ \\
\hline Corticosterone & $\mathrm{nmol} / \mathrm{L}$ & $847.1 \pm 129.2$ & $763.4 \pm 44.8^{\mathrm{c}}$ & $1095.7 \pm 104.1$ & $1174.2 \pm 42.8^{\mathrm{a}, \mathrm{c}}$ & $930.5 \pm 63.2^{\mathrm{b}}$ \\
\hline \multicolumn{7}{|l|}{ Blood } \\
\hline $\mathrm{HbA1c}$ & $\begin{array}{l}\% \\
(\mathrm{mmol} / \mathrm{mol})\end{array}$ & $\begin{array}{c}3.4 \pm 0.1^{\mathrm{c}} \\
(13.1 \pm 1.3)\end{array}$ & $\begin{array}{c}3.4 \pm 0.1^{\mathrm{c}} \\
(13.7 \pm 0.7)\end{array}$ & $\begin{array}{c}4.9 \pm 0.2 \\
(29.5 \pm 1.6)\end{array}$ & $\begin{array}{r}3.3 \pm 0.0^{\mathrm{c}} \\
(12.8 \pm 0.3)\end{array}$ & $\begin{aligned} 3.1 & \pm 0.1^{\mathrm{a}, \mathrm{b}, \mathrm{c}} \\
(10.4 & \pm 0.8)\end{aligned}$ \\
\hline \multicolumn{7}{|l|}{ Liver } \\
\hline \multirow[t]{2}{*}{ TG } & $\mathrm{mg} / \mathrm{g}$ & $3.7 \pm 0.4^{\mathrm{c}}$ & $3.1 \pm 0.7^{\mathrm{c}}$ & $43.7 \pm 1.5$ & $14.2 \pm 1.9^{\mathrm{a}, \mathrm{c}}$ & $9.9 \pm 0.8^{\mathrm{a}, \mathrm{c}}$ \\
\hline & $\mathrm{mg} /$ liver & $3.9 \pm 0.4^{\mathrm{c}}$ & $3.0 \pm 0.7^{\mathrm{c}}$ & $128.1 \pm 9.8$ & $20.3 \pm 2.9^{\mathrm{a}, \mathrm{c}}$ & $12.6 \pm 1.2^{\mathrm{a}, \mathrm{b}, \mathrm{c}}$ \\
\hline \multirow[t]{2}{*}{ Cholesterol } & $\mathrm{mg} / \mathrm{g}$ & $1.4 \pm 0.1^{\mathrm{c}}$ & $1.2 \pm 0.1^{\mathrm{c}}$ & $2.9 \pm 0.3$ & $1.6 \pm 0.1^{\mathrm{c}}$ & $1.7 \pm 0.1^{\mathrm{a}, \mathrm{c}}$ \\
\hline & $\mathrm{mg} /$ liver & $1.5 \pm 0.1^{\mathrm{c}}$ & $1.1 \pm 0.1^{\mathrm{b}, \mathrm{c}}$ & $8.6 \pm 1.0$ & $2.3 \pm 0.2^{\mathrm{a}, \mathrm{c}}$ & $2.1 \pm 0.1^{\mathrm{a}, \mathrm{c}}$ \\
\hline
\end{tabular}

Values are the mean $\pm \mathrm{SE}$

Values were analyzed by Student's $t$ test

$a d$ ad libitum-fed and sedentary, PSe pair-fed and sedentary, PEx pair-fed and exercising, Pair-fed condition food amount consumed by ad-WT mice was supplied, $B W$ Body weight, $W A T$ white adipose tissue, $F F A$ free fatty acids, $T G$ triglyceride

a $P<0.05$ vs. WT mice in each physical condition

b $P<0.05$ vs. ad-WT or PSe- $d b$ mice

${ }^{\mathrm{c}} P<0.05$ vs. ad- $d b$ mice

higher Glut4 and FAS than ad- $d b$ mice. In addition, $A C C 2$ was significantly higher in SM of PEx- $d b$ mice, than ad- $d b$ mice. There was a tendency toward higher $A C C l$ expression levels in WAT of PEx- $d b$ mice, as compared to ad- $d b$ mice $(P=0.13)$. Regarding BCAA metabolism, the three groups of $d b$ mice showed similar expression levels in branched-chain aminotransferase $(B C A T)$ 2, solute-linked carrier $(S L C) 3 A 2$ and 7A5 involved in BCAA transport, in $\mathrm{SM}$ and WAT, respectively.

\section{Discussion}

In the present study, VE under pair-fed conditions improved glucose, lipid, and AA metabolism in $d b$ mice more than food restriction only, based on the results regarding blood $\mathrm{HbA1c}$, hepatic TG content, and blood BCAA levels. Moreover, the exercise differently affected expressions of the genes related to lipid synthesis in insulin-sensitive organs such as the liver, SM, and WAT. 


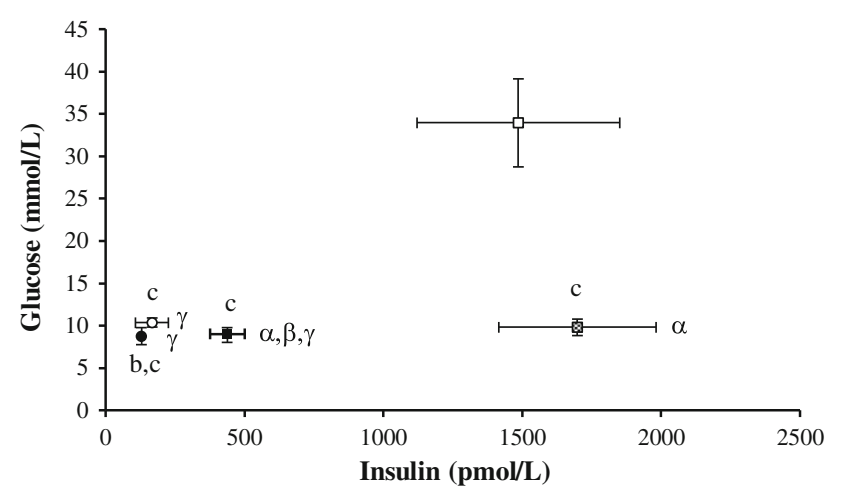

Fig. 2 Relationship between plasma insulin and glucose levels. Circles and squares represent WT and $d b$ mice, respectively. Open symbols represent ad libitum-fed mice under the sedentary condition. Hatched symbols represent pair-fed $d b$ mice under the sedentary condition. Closed symbols represent exercising mice under the pairfed condition (food amount consumed by ad libitum-fed WT mice was supplied). The values are the mean \pm SE. Values were analyzed by Student's $t$ test. For comparison of glucose and insulin between the groups, alphabetical and Greek letters are used for statistical significance, respectively. For glucose concentration; ${ }^{\mathrm{a}} P<0.05$ vs. WT mice in each physical condition. ${ }^{\mathrm{b}} P<0.05$ vs. ad-WT or PSe- $d b$ mice. ${ }^{\mathrm{c}} P<0.05$ vs. ad- $d b$ mice. For insulin concentration; ${ }^{\alpha} P<0.05$ vs. WT mice in each physical condition. ${ }^{\beta} P<0.05$ vs. ad-WT or PSe$d b$ mice. ${ }^{\gamma} P<0.05$ vs. ad- $d b$ mice

To the best of our knowledge, this is the first report to show successful treatment without any drugs for $d b$ mice, an animal model of T2DM. VE under pair-fed conditions reduced body, liver, and WAT weight in $d b$ mice. In addition, body weight per se and body weight gain fell in exercising mice (Fig. 1B, C), in contrast to high SM weight. The increase of the SM weight in $d b$ mice can be accounted for by an increase in the SM weight itself, and not only by a decrease in the body weight corresponding to a higher ratio of the SM weight/body weight (Fig. 1B; Table 1). Thus, the increased SM weight despite body weight decrease may be a beneficial effect of exercise under the diabetic condition, as compared with mere food restriction. The decreased liver weight may be caused by decreased TG content, suggesting that exercise is effective to suppress the development of fatty liver found in conditions with diabetes. This finding is consistent with reports on human studies [28, 29]. Interestingly, in the gene expression study, lipogenic enzyme genes such as $F A S$ and $A C C l$ in liver were lower in PEx- $d b$ mice than in ad- $d b$ mice (Fig. 3). On the other hand, in SM and WAT, the lipogenic enzyme genes were rather increased in PEx- $d b$ mice, indicating that exercise may have different influences on lipid metabolism in the respective organs sensitive to insulin action. Expression of Glut4 was increased in SM and WAT of PEx- $d b$ mice. Moreover, during the present study, $\mathrm{HbA} 1 \mathrm{c}$ was shown to be lower in PEx- $d b$ mice. As shown in Fig. 2, exercise may enhance insulin sensitivity, rather than only food restriction. Altogether, excess blood glucose in conditions with diabetes may be incorporated into SM and WAT based on high expression of GluT4 and lipogenic enzyme genes, leading to lipid synthesis enhanced by exercise as replenishment of triglyceride. This finding is consistent with reports on human studies [7, 8].

In rodents and humans with diabetes conditions including type 1 and type 2 , increased BCAA has been reported [18-20]. The underlying mechanism is involved in insulin resistance [30, 31]. Very recently, increased BCAA has been reported to be an important prospective factor for the onset of T2DM [20]. In the present study, exercise decreased BCAA in $d b$ mice more than food restriction in $d b$ mice. In $d b$ mice, branched-chain $\alpha$-keto acids such as isovaleric acid showed lower excretion in urine [32], indicating the slow degradation and transport of BCAA in WAT and SM, which are thought to play a role in BCAA metabolism [26, 27, 33]. The gene expressions of $B C A T 2$, $S L C 3 A 2$, and $S L C 7 A 5$, the responsible genes in BCAA degradation and transport, were not altered under exercise conditions in our models, except BCAT2 in SM (Fig. 3). Although the detailed underlying mechanism has not been clarified, VE could decrease blood BCAA to the WT mouse level, possibly due to improved insulin resistance (Fig. 2) and/or increased incorporation into skeletal muscle, corresponding to enlarged skeletal muscle related to enhancement of protein synthesis (Table 1). The enlarged skeletal muscle by VE was consistent with the previous report [23]. In exercising $d b$ mice, the decrease in arginine and ornithine through possible incorporation into the liver, intermediates of the urea cycle, suggests an important role in ammonia detoxification [34]. Proline and alanine (vs. Se- $d b$ mice, $P=0.06$ ), which decrease with exercise, may be utilized efficiently to form glucose in the liver [35]. However, it remains to be elucidated whether exercise enhanced hepatic gluconeogenesis.

Regarding the effect of exercise on hormone levels related to nutrient metabolism, exercise increased adiponectin and decreased leptin in blood (Table 1), leading to enhanced insulin sensitivity, as in humans [36, 37]. The altered levels of blood adiponectin and leptin cannot be explained by gene expressions in WAT because exercise did not significantly influence the expression level of adiponectin and leptin in WAT (data not shown). The underlying mechanism regarding the influence of exercise on blood adiponectin and leptin levels will be elucidated by this animal model. Regarding alterations of plasma corticosterone levels, fasting has been reported to increase plasma corticosterone [38, 39]. Interestingly, VE in the present study decreased plasma corticosterone in $d b$ mice, suggesting that the effects of exercise are not explained by the effects of longer fasting in association with increased energy expenditure. 
Table 2 Plasma amino acid concentrations in WT and $d b$ mice

\begin{tabular}{|c|c|c|c|c|c|}
\hline \multirow[b]{2}{*}{$\begin{array}{l}\text { Fed condition } \\
\text { Physical condition }\end{array}$} & \multicolumn{5}{|l|}{ Group } \\
\hline & $\begin{array}{l}\text { ad-WT } \\
\text { ad libitum } \\
\text { sedentary } \\
(N=4)\end{array}$ & $\begin{array}{l}\text { PEx-WT } \\
\text { Pair-fed } \\
\text { exercising } \\
(N=6)\end{array}$ & $\begin{array}{l}a d-d b \\
\text { ad libitum } \\
\text { sedentary } \\
(N=4)\end{array}$ & $\begin{array}{l}\text { PSe- } d b \\
\text { Pair-fed } \\
\text { sedentary } \\
(N=6)\end{array}$ & $\begin{array}{l}\text { PEx- } d b \\
\text { Pair-fed } \\
\text { exercising } \\
(N=6)\end{array}$ \\
\hline Alanine & $200.0 \pm 31.1$ & $256.9 \pm 14.7$ & $299.1 \pm 65.6$ & $293.3 \pm 6.0^{\mathrm{a}}$ & $246.6 \pm 20.7$ \\
\hline Arginine & $57.1 \pm 5.2^{\mathrm{c}}$ & $86.6 \pm 10.0$ & $79.3 \pm 5.4$ & $75.8 \pm 4.4^{\mathrm{a}}$ & $58.6 \pm 5.1^{\mathrm{a}, \mathrm{b}, \mathrm{c}}$ \\
\hline Asparagine & $25.9 \pm 1.8$ & $31.6 \pm 3.0$ & $21.8 \pm 2.9$ & $23.0 \pm 0.6$ & $18.3 \pm 2.5^{\mathrm{a}}$ \\
\hline Aspartic acid & $14.0 \pm 4.2$ & $13.2 \pm 1.8$ & $13.2 \pm 2.2$ & $20.4 \pm 2.2$ & $14.8 \pm 2.5$ \\
\hline Citrulline & $51.7 \pm 2.9^{c}$ & $66.4 \pm 4.7^{\mathrm{b}}$ & $93.7 \pm 13.1$ & $74.3 \pm 5.7^{\mathrm{a}}$ & $62.4 \pm 6.6^{\mathrm{c}}$ \\
\hline Cystine & $51.8 \pm 3.8$ & $57.9 \pm 2.5$ & $50.7 \pm 4.1$ & $38.7 \pm 1.6^{\mathrm{a}, \mathrm{c}}$ & $38.4 \pm 2.7^{\mathrm{a}, \mathrm{c}}$ \\
\hline Glutamic acid & $19.0 \pm 1.5$ & $15.9 \pm 2.3$ & $15.9 \pm 1.3$ & $19.9 \pm 3.2$ & $12.7 \pm 2.3$ \\
\hline Glutamine & $547.8 \pm 28.5^{\mathrm{c}}$ & $619.5 \pm 38.7$ & $723.8 \pm 51.5$ & $624.4 \pm 40.1$ & $637.2 \pm 38.4$ \\
\hline Glycine & $244.3 \pm 1.3^{\mathrm{c}}$ & $272.6 \pm 18.6^{\mathrm{c}}$ & $172.7 \pm 12.4$ & $193.0 \pm 5.7^{\mathrm{a}}$ & $191.4 \pm 17.2^{\mathrm{a}}$ \\
\hline Histidine & $45.4 \pm 1.4^{\mathrm{c}}$ & $58.5 \pm 4.3^{\mathrm{b}, \mathrm{c}}$ & $76.5 \pm 1.7$ & $40.5 \pm 3.0^{\mathrm{c}}$ & $39.7 \pm 5.0^{\mathrm{a}, \mathrm{c}}$ \\
\hline Isoleucine & $74.2 \pm 1.2^{\mathrm{c}}$ & $105.3 \pm 15.2^{\mathrm{c}}$ & $219.4 \pm 44.8$ & $115.5 \pm 10.2^{\mathrm{a}, \mathrm{c}}$ & $77.7 \pm 6.2^{\mathrm{b}, \mathrm{c}}$ \\
\hline Leucine & $109.8 \pm 5.3^{\mathrm{c}}$ & $163.9 \pm 24.3^{\mathrm{c}}$ & $349.3 \pm 76.0$ & $184.5 \pm 17.3^{\mathrm{a}, \mathrm{c}}$ & $118.5 \pm 9.4^{\mathrm{b}, \mathrm{c}}$ \\
\hline Lysine & $177.5 \pm 11.9$ & $229.7 \pm 19.0$ & $217.0 \pm 22.0$ & $176.8 \pm 14.4$ & $152.0 \pm 18.7^{\mathrm{a}}$ \\
\hline Methionine & $51.3 \pm 4.8$ & $76.8 \pm 6.8^{\mathrm{b}, \mathrm{c}}$ & $39.9 \pm 5.4$ & $45.0 \pm 2.3$ & $39.4 \pm 4.5^{\mathrm{a}}$ \\
\hline Ornithine & $49.1 \pm 5.7$ & $80.0 \pm 15.0$ & $45.3 \pm 9.7$ & $44.2 \pm 4.6$ & $28.1 \pm 3.7^{\mathrm{a}, \mathrm{b}}$ \\
\hline Phenylalanine & $56.2 \pm 4.3^{\mathrm{c}}$ & $80.8 \pm 8.3$ & $103.8 \pm 14.6$ & $70.3 \pm 5.2^{\mathrm{c}}$ & $54.2 \pm 5.9^{\mathrm{a}, \mathrm{c}}$ \\
\hline Proline & $73.0 \pm 8.6$ & $105.3 \pm 12.1$ & $82.5 \pm 19.2$ & $90.6 \pm 5.6$ & $67.3 \pm 7.5^{\mathrm{a}, \mathrm{b}}$ \\
\hline Serine & $96.3 \pm 2.6$ & $134.4 \pm 9.6^{\mathrm{b}, \mathrm{c}}$ & $90.5 \pm 4.8$ & $81.0 \pm 3.2^{\mathrm{a}}$ & $76.6 \pm 7.7^{\mathrm{a}}$ \\
\hline Threonine & $126.8 \pm 10.9$ & $192.5 \pm 17.1^{\mathrm{b}, \mathrm{c}}$ & $121.2 \pm 13.0$ & $141.2 \pm 7.8$ & $109.6 \pm 14.2^{\mathrm{a}}$ \\
\hline Tryptophan & $49.8 \pm 3.7^{\mathrm{c}}$ & $66.3 \pm 9.2^{\mathrm{c}}$ & $95.6 \pm 4.8$ & $59.7 \pm 5.8^{\mathrm{c}}$ & $44.9 \pm 3.9^{\mathrm{c}}$ \\
\hline Tyrosine & $61.9 \pm 7.8$ & $65.0 \pm 11.1$ & $86.0 \pm 22.9$ & $48.9 \pm 3.9$ & $36.1 \pm 3.4^{\mathrm{a}, \mathrm{b}, \mathrm{c}}$ \\
\hline Valine & $213.6 \pm 5.0^{\mathrm{c}}$ & $313.5 \pm 34.9$ & $508.1 \pm 92.7$ & $396.5 \pm 27.8^{\mathrm{a}}$ & $263.1 \pm 24.6^{\mathrm{b}, \mathrm{c}}$ \\
\hline BCAA & $397.6 \pm 10.6^{\mathrm{c}}$ & $582.7 \pm 74.3^{\mathrm{c}}$ & $1076.8 \pm 212.4$ & $696.4 \pm 55.0^{\mathrm{a}}$ & $459.3 \pm 39.4^{\mathrm{b}, \mathrm{c}}$ \\
\hline
\end{tabular}

Values are the mean $\pm \mathrm{SE}$

Values were analyzed by Student's $t$ test

$a d$ ad libitum fed and sedentary, PSe pair-fed and sedentary. PEx pair-fed and exercising, Pair-fed condition food amount consumed by ad-WT mice was supplied, $B C A A$ branched-chain amino acids

${ }^{a} P<0.05$ vs. WT mice in each physical condition

b $P<0.05$ vs. ad-WT or PSe- $d b$ mice

${ }^{\text {c }} P<0.05$ vs. ad- $d b$ mice

To evaluate the effect of exercise, VE should be combined with food restriction. With food restriction, $d b$ mice performed a relatively high amount of exercise compared to ad- $d b$ mice. This result is consistent with a report by Stranahan et al. [17]. The pair-fed condition in the present study, one type of food restriction, may relieve the suppression of orexin-dopamine signaling, leading to an increased amount of VE, by improving hyperglycemia. Keller et al. [40] have already shown that the amount of VE performed correlates with blood glucose in animals with diabetes. The findings suggest that dietary intervention reducing energy intake may increase the motivation to exercise, resulting in efficient effects of exercise on diabetic conditions.
There is a limitation of the study. The experiments were performed using an animal model with a genetically deficient leptin receptor. Although the mice are an animal model of T2DM, they are not the same as diabetes in human cases. Although high blood leptin levels corresponding to leptin resistance are similar to the pathological situation in human cases of T2DM [41], the results obtained here should be applied cautiously to humans.

In conclusion, we have established an animal model of T2DM evaluating the effects of exercise on diabetic conditions by means of a pair-fed procedure. Using this model, we found that exercise decreases several amino acids, including BCAA, and may improve insulin sensitivity more than mere food restriction. In other words, the 

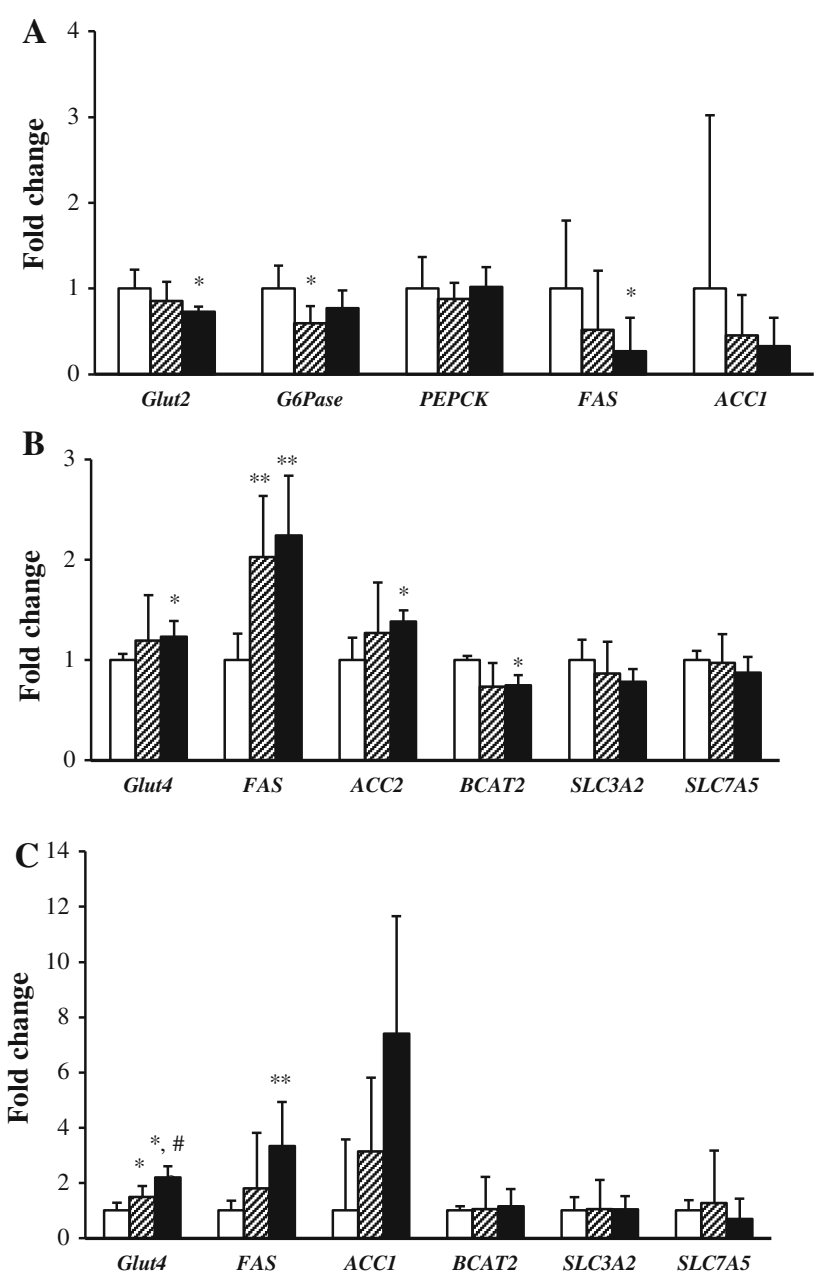

Fig. 3 Gene expressions in the liver (a), skeletal muscle (SM, b), and white adipose tissue (WAT, c). The values are shown as relative fold change over ad libitum $d b$ (ad- $d b$ ) mice (all values were set at 1.0). Open column, ad- $d b$ mice; hatched column, pair-fed and sedentary $d b$ mice; closed column, pair-fed and exercising $d b$ mice. Food amount consumed by ad libitum-fed WT mice was supplied as the pair-fed condition. The values are the means + SE. Values were analyzed by Student's $t$ test. $* P<0.05, * * P<0.01$ vs. ad- $d b$ mice; ${ }^{*} P<0.05$ vs. PSe- $d b$ mice

decreased AA concentration in blood may be utilized as a valuable marker to evaluate the efficiency of exercise on diabetic conditions. This view will be evaluated in further experiments in humans.

Acknowledgments This study was supported by a grant from the Ministry of Education, Science, Sports and Culture of Japan. We thank Ms. Chiko Nishinosono for secretarial assistance and Mr. Daniel Mrozek for copyediting. We wish to thank the Joint Research Laboratory, Kagoshima University Graduate School of Mental and Dental Sciences, for the use of their facilities. We thank all the staff members of the Institute of Laboratory Animal Sciences, Kagoshima University who kept the animals in a good condition.

Conflict of interest None.

\section{References}

1. Zimmet P, Alberti KGMM, Shaw J. Global and societal implications of the diabetes epidemic. Nature. 2001;414(6865):782-7.

2. Magkos F, Yannakoulia M, Chan JL, Mantzoros CS. Management of the metabolic syndrome and type 2 diabetes through lifestyle modification. Annu Rev Nutr. 2009;29:223-56.

3. Jafar-Mohammadi B, McCarthy MI. Genetic of type 2 diabetes mellitus and obesity-a review. Ann Med. 2008;40(1):2-10.

4. Lindgren CM, McCarthy MI. Mechanism of disease: genetic insights into the etiology of type 2 diabetes and obesity. Nat Clin Pract. 2008;4(3):156-63.

5. DiPietro L. Physical activity in aging: changes in patterns and their relationship to health and function. $\mathrm{J}$ Gerontrol. 2001;56A(2):13-22.

6. Sigal RJ, Kenny GP, Wasserman DH, Castaneda-Sceppa C, White RD. Physical activity/exercise and type 2 diabetes. Diabetes Care. 2006;29(6):1433-8.

7. Dela F, Larsen JJ, Mikines KJ, Ploug T, Petersen LN, Galbo H. Insulin-stimulated muscle glucose clearance in patients with NIDDM. Effects of one-legged physical training. Diabetes. 1995;44(9):1010-20.

8. Stallknecht B, Larsen JJ, Mikines KJ, Simonsen L, Bülow J, Galbo $\mathrm{H}$. Effect of training on insulin sensitivity of glucose uptake and lipolysis in human adipose tissue. Am J Physiol Endocrinol Metab. 2000;279(2):E376-85.

9. Tang T, Reed MJ. Exercise adds to metformin and acarbose efficacy in $d b / d b$ mice. Metabolism. 2001;50(9):1049-53.

10. Huang H, Iida KT, Sone H, Yokoo T, Yamada N, Ajisaka R. The effect of exercise training on adiponectin receptor expression in KKAy obese/diabetic mice. J Endocrinol. 2006;189(3):643-53.

11. Haskell-Luevano C, Schaub JW, Andreasen A, Haskell KR, Moore MC, Koerper LM, et al. Voluntary exercise prevents the obese and diabetic metabolic syndrome of the melanocortin-4 receptor knockout mouse. FASEB J. 2009;23(2):642-55.

12. Sennott J, Morrissey J, Standley PR, Broderick TL. Treadmill exercise training fails to reverse defects in glucose, insulin and muscle GLUT4 content in the $d b / d b$ mouse models of diabetes. Pathophysiology. 2008;15(3):173-9.

13. Parrot CR, Ghosh P, Tedeschi J, Gunasekara G, Broderick TL. Urinary corticosterone and normetanephrine levels after voluntary wheel and forced treadmill running in the $d b / d b$ mouse. J Diabetes Mellitus. 2011;1(4):71-8.

14. Pan A, Lucas M, Sun Q, van Dam RM, Franco OH, Manson JE, et al. Bidirectional association between depression and type 2 diabetes mellitus in women. Arch Intern Med. 2010;170(21): 1884-91.

15. Cox JE, Powley TL. Development of obesity in diabetic mice pair-fed with lean siblings. J Comp Physiol Psychol. 1977;91(2): 347-58.

16. Yamamoto Y, Ueta Y, Serino R, Nomura M, Shibuya I, Yamashita H. Effects of food restriction on the hypothalamic prepro-orexin gene expression in genetically obese mice. Brain Res Bull. 2000;51(6):515-21.

17. Stranahan AM, Lee K, Martin B, Martin B, Maudsley S, Golden $\mathrm{E}$, Cutler R, et al. Voluntary exercise and caloric restriction enhance hippocampal dendritic spine density and BDNF levels in diabetic mice. Hippocampus. 2009;19(10):951-61.

18. Wijekoon EP, Skinner C, Brosnan ME, Brosnan JT. Amino acid metabolism in the Zucker diabetic fatty rat: effects of insulin resistance and of type 2 diabetes. Can J Physiol Pharmacol. 2004;82(7):506-14.

19. She P, Horn CV, Reid T, Hutson SM, Cooney RN, Lynch CJ. Obesity-related elevations in plasma leucine are associated with alteration in enzymes involved in branched chain amino acid 
metabolism. Am J Physiol Endocrinol Metab. 2007;293(6): E1552-63.

20. Wang TJ, Larson MG, Vasan RS, Cheng S, Rhee EP, McCabe E, et al. Metabolite profiles and the risk of developing diabetes. Nat Med. 2011;17(4):448-53.

21. Chen H, Charlat O, Tartaglia LA, Woolf EA, Weng X, Ellis SJ, et al. Evidence that the diabetes gene encodes the leptin receptor: identification of a mutation in the leptin receptor gene in $\mathrm{db} / \mathrm{db}$ mice. Cell. 1996;84(3):491-5.

22. Arimura E, Horiuchi M, Kawaguchi H, Miyoshi N, Aoyama K, Takeuchi T. Low-protein diet improves blood and urinary glucose levels and renal manifestations of diabetes in C57BLKS- $d b$ / $d b$ mice. Eur J Nutr. 2013;52(2):813-24.

23. Takeshita H, Horiuchi M, Izumo K, Kawaguchi H, Arimura E, Aoyama K, et al. Long-term voluntary exercise, representing habitual exercise, lowers visceral fat and alters plasma amino acid levels in mice. Environ Health Prev Med. 2012;17(4):275-84.

24. Wang Q, Li S, Jiang L, Jiang L, Zhou Y, Li Z, Shao M, et al. Deficiency in hepatic ATP-citrate lyase affects VLDL-triglyceride mobilization and liver fatty acid composition in mice. J Lipid Res. 2010;51(9):2516-26.

25. Chomczynski P, Sacchi N. Single-step method of RNA isolation by acid guanidinium thiocyanate-phenol-chloroform extraction. Anal Biochem. 1987;162(1):156-9.

26. She P, Reid TM, Bronson SK, Vary TC, Hajnal A, Lynch CJ, et al. Disruption of BCATm in mice leads to increased energy expenditure associated with the activation of a futile protein turnover cycle. Cell Metab. 2007;6(3):181-94.

27. Drummond MJ, Fry CS, Glynn EL, Timmerman KL, Dicknson JM, Walker DK, et al. Skeletal muscle amino acid transporter expression is increased in young and older adults following resistance exercise. J Appl Physiol. 2011;111(1):135-42.

28. Bae JC, Suh S, Park SE, Rhee EJ, Park CY, Oh KW, Park SW, et al. Regular exercise is associated with a reduction in the risk of NAFLD and decreased liver enzymes in individuals with NAFLD independent of obesity in Korean adults. PLoS ONE. 2012;7(10):e46819.

29. Rodriguez B, Torres DM, Harrison SA. Physical activity: an essential component of lifestyle modification in NAFLD. Nat Rev Gastroenterol Hepatol. 2012;12(6):726-31.
30. Newgard CB. Interplay between lipids and branched-chain amino acids in development of insulin resistance. Cell Metab. 2012;15(5):606-14.

31. Lu J, Xie G, Jia W, Jia W. Insulin resistance and the metabolism of branched-chain amino acids. Front Med. 2013;7(1):53-9.

32. Kandár R, Žáková P, Jirošová J, Sladká M. Determination of branched chain amino acids, methionine, phenylalanine, tyrosine and $\alpha$-keto acids in plasma and dried blood samples using HPLC with fluorescence detection. Clin Chem Lab Med. 2009; 47(5):565-72.

33. She P, Zhou Y, Zhang Z, Griffin K, Gowda K, Lynch CJ. Disruption of BCAA metabolism in mice impairs exercise metabolism and endurance. J Appl Physiol. 2010;108(4):941-9.

34. Krebs HA, Hems R, Lund P. Sources of ammonia for mammalian urea synthesis. Biochem J. 1978;176(3):733-7.

35. Krebs HA, Notton BM, Hems R. Gluconeogenesis in mouse-liver slices. Biochem J. 1966;101(3):607-17.

36. Jürimäe J, Kums T, Jürimäe T. Plasma adiponectin concentration is associated with the average accelerometer daily steps counts in healthy elderly females. Eur J Appl Physiol. 2010;109(5):823-8.

37. Sahin-Efe A, Katsikeris F, Mantzoros CS. Advances in adipokines. Metabolism. 2012;61(12):1659-65.

38. Makimura H, Mizuno TM, Yang X-J, Silverstein J, Beasley J, Mobbs CV. Cerulenin mimics effects of leptin on metabolic rate, food intake, and body weight independent of the melanocortin system, but unlike leptin, cerulenin fails to block neuroendocrine effects of fasting. Diabetes. 2001;50(4):733-9.

39. Sakoguchi T, Horiuchi M, Asakawa A, Ushikai M, Yoshida G, Fujimiya M, et al. Failure of the feeding response to fasting in carnitine-deficient juvenile visceral steatosis (JVS) mice: involvement of defective acyl-ghrelin secretion and enhanced corticotropin-releasing factor signaling in the hypothalamus. Biochim Biophys Acta. 2009;1792(11):1087-93.

40. Keller JB, Bevier WC, Jovanovic-Peterson L, Formby B, Durak EP, Peterson CM. Voluntary exercise improves glycemia in nonobese diabetic (NOD) mice. Diabetes Res Clin Pract. 1993;22(1):29-35.

41. Martin SS, Qasim A, Reilly MP. Leptin resistance. J Am Coll Cardiol. 2008;52(15):1201-10. 